\title{
Lead Poisoning: Awareness in Medical and Non-Medical Population of Karachi
}

\author{
Sana Sarfaraz*, Aqsa Naz, Amber Shahid, Maryam Qayyum \\ Faculty of Pharmacy, Jinnah University for Women, Karachi-74600, Pakistan
}

doi: https://doi.org/10.21467/ajgr.1.1.3-13

* Corresponding Author email:

sana.sarfraz@live.com

Article History

Received: 29 November 2016

Revised: 07 December 2016

Accepted: 24 December 2016

Published: 27 December 2016

Student(s)

- Aqsa Naz

- Amber Shahid

- Maryam Qayyum

Academic Year: 2016-17, I ${ }^{\text {st }}$ Semester

Course Level: Bachelor Degree

Course Name: Clinical Pharmacy

Course year: $4^{\text {th }}$ year $/$ VII ${ }^{\text {th }}$ Semester

Mentar(s)

Sana Sarfaraz

\begin{abstract}
Lead is a heavy element, also termed as nerve poison. Lead interferes with a variety of body processes and is toxic to many organs and tissues, including the central nervous system. The purpose of this study is to evaluate awareness regarding lead poisoning, factors that cause lead poisoning, symptoms, effect on enzymes, treatment and preventive measure that can be adopted to reduce lead poisoning in our population. It is a descriptive cross sectional survey based study consisting of 300 individuals comprising of 100 medical professionals and 200 laypersons (100 from Literate and 100 from Illiterate Population). The study was carried out from different locations in Karachi and answers were recorded as open and close ended. Our study showed that 95\% medical professionals, 53\% Literate layperson whereas only $29 \%$ Illiterate layperson were aware about lead poisoning. 38\% Literate, $27 \%$ Illiterate and $54 \%$ medical professional knew about the sources of lead poisoning. $82 \%$ medical professionals, $17 \%$ Literate laypersons were aware about pharmacological intervention and there was no awareness among Illiterate Population.
\end{abstract}

Keywords: Lead poisoning, Nerve toxin, CNS damage, dietary sources, Chelation therapy

\section{Introduction}

Potare is a Latin word from which the word poison has been derived which means to drink. Poison can kill or injure anything through its chemical actions [1]. Poison can affect the body through ingestion, can be inhaled and injected through the skin by altering the normal body physiology [2]. Poisoning can be classified in two major groups. One group consist of those products that should never be inhaled or ingested even in small amounts such as shampoo, paint thinner, pesticides, houseplant leaves and carbon monoxide. While other group consists of those products that can be ingested in small amount but they become harmful if consumed 
in large amounts such as pharmaceuticals, medicinal herbs and alcohol [3]. The damage caused by the poisoning depends on the type, amount, age and underline health of the person whose consumed the poison [4]. Lead is a naturally occurring element found in small amounts in the air, the soil, the water and even inside our homes. [5] Even though it's found in small amounts; there is an abundant supply of lead throughout the earth. Because it is widespread, easy to extract and easy to work with poisoning can commonly occur with it. While it has some beneficial uses, it can be toxic to humans and animals causing hazardous effects [6].

Lead poisoning is a serious and sometimes fatal condition [7]. Exposure to lead occurs in several ways: Drinking water pumped through lead pipes, working in jobs where lead is used (industries), spending time in areas with deteriorating lead-based paint, using traditional medicines that contain lead, contaminated soil, cosmetics, household products (utensils, batteries) and toys [8]. The effects of lead in adult are the same irrespective of the route through which it enters. The main target in the body for lead toxicity is the nervous system [9]. High blood lead levels are associated with nerve disorders, cardiovascular effects, decreased kidney function, and fertility problems. Increases in blood pressure, hypertension, and incidence of essential tremor are also common symptoms. Maternal high blood lead levels are associated with reduced fetal growth and early delivery [10]. Children are more vulnerable to lead poisoning than adults because their nervous systems are under developed [11]. Children's bodies absorb more of the lead than adult bodies because it is easier to be exposed to the dirt or dust on their hands, toys or other items that may contain lead [12]. Lead poisoning can cause mild to severe effects on children by affecting all the systems in the body. Even low levels of lead are harmful and can cause decreased intelligence, effecting nervous system and brain. levels leads to cognitive disease, inability to learn, writing, reading, hearing becomes impaired, causes irritability, insomnia, slow muscles and bone growth, seizures and even death [13]. Adverse symptoms a can occur even at low blood lead levels $1 \mu \mathrm{g} / \mathrm{dL}$, including lower intelligence quotient(IQ) scores, decreased academic achievement, and increases in both behavioral problems and attention-related behaviors [14]. Blood tests are performed to detect increase level of lead in body [15]. For reducing lead absorption, the key nutrients appear to be vitamin $\mathrm{C}$, calcium, iron and to a lesser degree, zinc and phosphorus. Dietary deficiencies in any of these can increase lead absorption [16]. Different vitamins play a role in eliminating lead from the body. Vitamin D and Vitamin B9 (Folate) act by increasing lead absorption in the body which leads to decreased concentration of lead stores in body. Vitamin B1 (thiamine) increases lead excretion from brain [17]. In pharmacological treatment, chelation therapy can be used. [18]. A chemical Ethylene diamine tetra acetic acid (EDTA) may also be used but it can be hard to reverse the effects of chronic exposure to lead [19] as well as Penicillamine [20] and 2, 3Dimercaptosuccinic acid also used to eliminate lead from the body [21].

Objective of study is to evaluate knowledge and awareness about lead poisoning among different health care professionals and laypersons (literate and Illiterate) considering the facts that which factors promote lead poisoning, causes, symptoms and treatment protocols as well as preventive measure to be taken to reduce the risk of lead poisoning.

\section{Methodology}

It is a descriptive cross sectional based study comprising of $\mathrm{N}=300$ consisting of 100 laypersons of both literate and Illiterate population whereas $\mathrm{N}=100$ were medical personnel. The age group targeted was 20-45 years. Both males and females participated in the study. The study was carried out between February 2016 and April 2016. The questionnaire was based on 14 questions as given in Table 1. The survey forms were distributed among the individuals after their consent from different locations in Karachi. The Medical population were evaluated from different private and public hospitals in Karachi. The questions were explained to the individuals and the forms were collected after they filled. The individuals freely participated in the survey and the answers were recorded as both open and close ended. 
Sarfaraz et al., Adv. J. Grad. Res.; Vol. 1 Issue 1, pp: 3-13, January 2017

Table 1: Questionnaire and response evaluation of populations regarding lead poisoning awareness

\begin{tabular}{|c|c|c|c|c|c|}
\hline $\begin{array}{l}\text { S. } \\
\text { N. }\end{array}$ & Questions & Options & Medical & $\begin{array}{l}\text { Literate } \\
\text { Laypersons }\end{array}$ & $\begin{array}{l}\text { Illiterate } \\
\text { Laypersons }\end{array}$ \\
\hline \multirow[t]{2}{*}{1.} & \multirow[t]{2}{*}{ Awareness about Lead poisoning } & YES & $95 \%$ & $53 \%$ & $23 \%$ \\
\hline & & NO & $5 \%$ & $47 \%$ & $77 \%$ \\
\hline \multirow[t]{4}{*}{2.} & \multirow{4}{*}{$\begin{array}{l}\text { Which type of population mostly } \\
\text { effected by Lead poisoning }\end{array}$} & CHILDREN & $73 \%$ & $72 \%$ & $71 \%$ \\
\hline & & TEENAGERS & $7 \%$ & $17 \%$ & $11 \%$ \\
\hline & & ADULT & $18 \%$ & $9 \%$ & $9 \%$ \\
\hline & & ELDERLY & $2 \%$ & $2 \%$ & $9 \%$ \\
\hline \multirow[t]{10}{*}{3.} & \multirow[t]{10}{*}{ Sources of Lead poisoning } & PAINTS & $10 \%$ & $18 \%$ & $7 \%$ \\
\hline & & TOYS & $0 \%$ & $1 \%$ & $0 \%$ \\
\hline & & UTENSILS & $3 \%$ & $3 \%$ & $18 \%$ \\
\hline & & PLUMBING & $0 \%$ & $3 \%$ & $23 \%$ \\
\hline & & POLLUTION & $18 \%$ & $11 \%$ & $17 \%$ \\
\hline & & COSMETICS & $3 \%$ & $6 \%$ & $0 \%$ \\
\hline & & PENCILS & $11 \%$ & $6 \%$ & $0 \%$ \\
\hline & & SOIL & $1 \%$ & $14 \%$ & $8 \%$ \\
\hline & & ALL & $54 \%$ & $38 \%$ & $27 \%$ \\
\hline & & NONE & $0 \%$ & $0 \%$ & $0 \%$ \\
\hline \multirow[t]{4}{*}{4.} & \multirow[t]{4}{*}{$\begin{array}{l}\text { Most common effect of Lead } \\
\text { poisoning }\end{array}$} & $\begin{array}{l}\text { MENTAL } \\
\text { IMPAIREMENT }\end{array}$ & $38 \%$ & $30 \%$ & $12 \%$ \\
\hline & & BONE WEAKNESS & $16 \%$ & $27 \%$ & $37 \%$ \\
\hline & & KIDNEY DISEASE & $3 \%$ & $18 \%$ & $41 \%$ \\
\hline & & $\begin{array}{l}\text { NEUROLOGICAL } \\
\text { EFFECT }\end{array}$ & $43 \%$ & $25 \%$ & $10 \%$ \\
\hline \multirow[t]{5}{*}{5.} & \multirow{5}{*}{$\begin{array}{l}\text { Common route involve in Lead } \\
\text { poisoning }\end{array}$} & INHALATION & $10 \%$ & $26 \%$ & $7 \%$ \\
\hline & & ORAL & $16 \%$ & $32 \%$ & $73 \%$ \\
\hline & & SUBCUTANEOUS & $1 \%$ & $5 \%$ & $0 \%$ \\
\hline & & ORAL+INHALE & $73 \%$ & $35 \%$ & $20 \%$ \\
\hline & & ALL & $0 \%$ & $2 \%$ & $0 \%$ \\
\hline \multirow[t]{2}{*}{6.} & \multirow{2}{*}{$\begin{array}{l}\text { Lead effect unborn babies during } \\
\text { pregnancy? }\end{array}$} & YES & $95 \%$ & $69 \%$ & $11 \%$ \\
\hline & & $\mathrm{NO}$ & $5 \%$ & $34 \%$ & $89 \%$ \\
\hline \multirow[t]{4}{*}{7.} & \multirow{4}{*}{$\begin{array}{l}\text { Through which route Lead effect } \\
\text { unborn babies }\end{array}$} & COSMETIC & $33 \%$ & $30 \%$ & $0 \%$ \\
\hline & & POLLUTION & $37 \%$ & $50 \%$ & $3 \%$ \\
\hline & & PLUMBING & $5 \%$ & $5 \%$ & $7 \%$ \\
\hline & & UTENSIL & $25 \%$ & $15 \%$ & $2 \%$ \\
\hline \multirow[t]{2}{*}{8.} & \multirow{2}{*}{$\begin{array}{l}\text { Iron, Calcium and Vit } \mathrm{C} \text { defiency } \\
\text { indicate lead poisoning? }\end{array}$} & YES & $71 \%$ & $52 \%$ & $19 \%$ \\
\hline & & $\mathrm{NO}$ & $29 \%$ & $48 \%$ & $81 \%$ \\
\hline \multirow[t]{7}{*}{9.} & \multirow{7}{*}{$\begin{array}{l}\text { Common sources that contain } \\
\text { Iron, Calcium and Vitamin } C\end{array}$} & MILK & $36 \%$ & $45 \%$ & $77 \%$ \\
\hline & & YOGURT & $11 \%$ & $25 \%$ & $2 \%$ \\
\hline & & BANANA & $12 \%$ & $7 \%$ & $3 \%$ \\
\hline & & ORANGE & $11 \%$ & $7 \%$ & $13 \%$ \\
\hline & & MEAT & $6 \%$ & $7 \%$ & $5 \%$ \\
\hline & & CHEESE & $19 \%$ & $5 \%$ & $0 \%$ \\
\hline & & OTHER & $5 \%$ & $4 \%$ & $0 \%$ \\
\hline \multirow[t]{2}{*}{10.} & \multirow{2}{*}{$\begin{array}{l}\text { Vitamin B1 and Vitamin D help to } \\
\text { excrete lead from brain and bone } \\
\text { respectively? }\end{array}$} & YES & $78 \%$ & $51 \%$ & $7 \%$ \\
\hline & & $\mathrm{NO}$ & $22 \%$ & $49 \%$ & $93 \%$ \\
\hline
\end{tabular}


Lead Poisoning: Awareness in Medical and Non-Medical Population of Karachi

\begin{tabular}{|c|c|c|c|c|c|}
\hline \multirow[t]{5}{*}{11.} & \multirow{5}{*}{$\begin{array}{l}\text { Which Herbal remedies useful to } \\
\text { treat lead poisoning }\end{array}$} & GLYCERRHIZA & $0 \%$ & $7 \%$ & $15 \%$ \\
\hline & & TURMERIC & $11 \%$ & $30 \%$ & $47 \%$ \\
\hline & & SAUNF & $9 \%$ & $18 \%$ & $31 \%$ \\
\hline & & ALL & $45 \%$ & $20 \%$ & $7 \%$ \\
\hline & & OTHER & $35 \%$ & $25 \%$ & - \\
\hline \multirow[t]{2}{*}{12.} & \multirow{2}{*}{$\begin{array}{l}\text { Aware about pharmacological } \\
\text { treatment of Lead poisoning? }\end{array}$} & YES & $82 \%$ & $17 \%$ & $3 \%$ \\
\hline & & $\mathrm{NO}$ & $18 \%$ & $83 \%$ & $97 \%$ \\
\hline \multirow[t]{5}{*}{13.} & \multirow{5}{*}{$\begin{array}{l}\text { Which drug use to treat Lead } \\
\text { poisoning }\end{array}$} & CHELLATION & $30 \%$ & $25 \%$ & $1 \%$ \\
\hline & & EDTA & $22 \%$ & $18 \%$ & - \\
\hline & & PENICILLAMINE & $0 \%$ & $3 \%$ & $2 \%$ \\
\hline & & ALL & $47 \%$ & $16 \%$ & - \\
\hline & & OTHER & $1 \%$ & $38 \%$ & $97 \%$ \\
\hline \multirow[t]{4}{*}{14.} & \multirow{4}{*}{$\begin{array}{l}\text { Preventive action to overcome } \\
\text { Lead poisoning }\end{array}$} & AWARNESS & $68 \%$ & $63 \%$ & $67 \%$ \\
\hline & & HEALTHY DIET & $8 \%$ & $14 \%$ & $3 \%$ \\
\hline & & ABATEMENT & $15 \%$ & $6 \%$ & $1 \%$ \\
\hline & & WASH HANDS & $9 \%$ & $17 \%$ & $29 \%$ \\
\hline
\end{tabular}

\section{Results and Discussion}

The results were evaluated using Microsoft excel 2010 as shown in Table 1 and SPSS version 20 as shown in Table 2. One way Anova was applied. Post hoc analysis Tukey's analysis was done and P values were expressed showing significance difference of data.

Table 2: Comparative Evaluation of Medical Population versus Layperson regarding awareness of lead poisoning

\begin{tabular}{|c|c|c|}
\hline Questions & $\begin{array}{c}\text { Medical Population } \\
\text { Vs } \\
\text { Literate Laypersons }\end{array}$ & $\begin{array}{c}\text { Medical Population } \\
\text { Vs } \\
\text { Illiterate Laypersons }\end{array}$ \\
\hline Awareness about Lead poisoning & $\mathrm{P}<0.001 \quad * * *$ & $\mathrm{P}<0.001 * * *$ \\
\hline Which type of population mostly effected by Lead poisoning & $\mathrm{P}<0.79$ & $\mathrm{P}<0.82 \quad$ IS \\
\hline Sources of Lead poisoning & $\mathrm{P}<0.69$ & $\mathrm{P}<0.002 * *$ \\
\hline Most common effect of Lead poisoning & $\mathrm{P}<0.786 \quad$ IS & $\mathrm{P}<0.02 * *$ \\
\hline Common route involve in Lead poisoning & $\mathrm{P}<0.001$ & $\mathrm{P}<0.001 \quad * * *$ \\
\hline Lead effect unborn babies during pregnancy? & $\mathrm{P}<0.001$ & $\mathrm{P}<0.001 \quad * * *$ \\
\hline Iron, Calcium and Vit $\mathrm{C}$ defiency indicate lead poisoning? & $\mathrm{P}<0.005$ & $\mathrm{P}<0.001 \quad * * *$ \\
\hline Common sources that contain Iron, Calcium and Vitamin C & $\mathrm{P}<0.004 * *$ & $\mathrm{P}<0.001 \quad * * *$ \\
\hline $\begin{array}{l}\text { Vitamin B1 and Vitamin D help to excrete lead from brain and } \\
\text { bone respectively? }\end{array}$ & $\mathrm{P}<0.001 * * *$ & $\mathrm{P}<0.001$ \\
\hline Which Herbal remedies useful to treat lead poisoning & $\mathrm{P}<0.001 \quad * * *$ & $\mathrm{P}<0.001$ \\
\hline Aware about pharmacological treatment of Lead poisoning? & $\mathrm{P}<0.001 \quad * * *$ & $\mathrm{P}<0.001$ \\
\hline Which drug use to treat Lead poisoning & $\mathrm{P}<0.001 \quad * * *$ & $\mathrm{P}<0.001$ \\
\hline Preventive action to overcome Lead poisoning & $\mathrm{P}<0.75 \quad$ IS & $\mathrm{P}<0.26 \quad$ IS \\
\hline
\end{tabular}

SPSS Version 20 has been used. One way Anova applied. Post hoc analysis by Tukeys test shows p values as $\mathrm{P}<0.05$ significant *

$\mathrm{P}<0.01$ moderately significant $* *$

$\mathrm{P}<0.001$ highly significant $* * *$ 
Lead is a heavy metal also consider as nerve poison. It is a widespread, non-degradable, environmental toxicant [22]. Lead accumulates in the environment and contaminates the water, soil, air and food chain leading to human diseases. When it accumulates in the body from any source and cross normal level it causes toxicity [23]. Table 1 and Figure 1 show awareness regarding lead poisoning in literate layperson population is $53 \%$ while in illiterate population awareness rate is very low i.e $23 \%$. Among medical professional's $95 \%$ population is aware about lead poisoning.

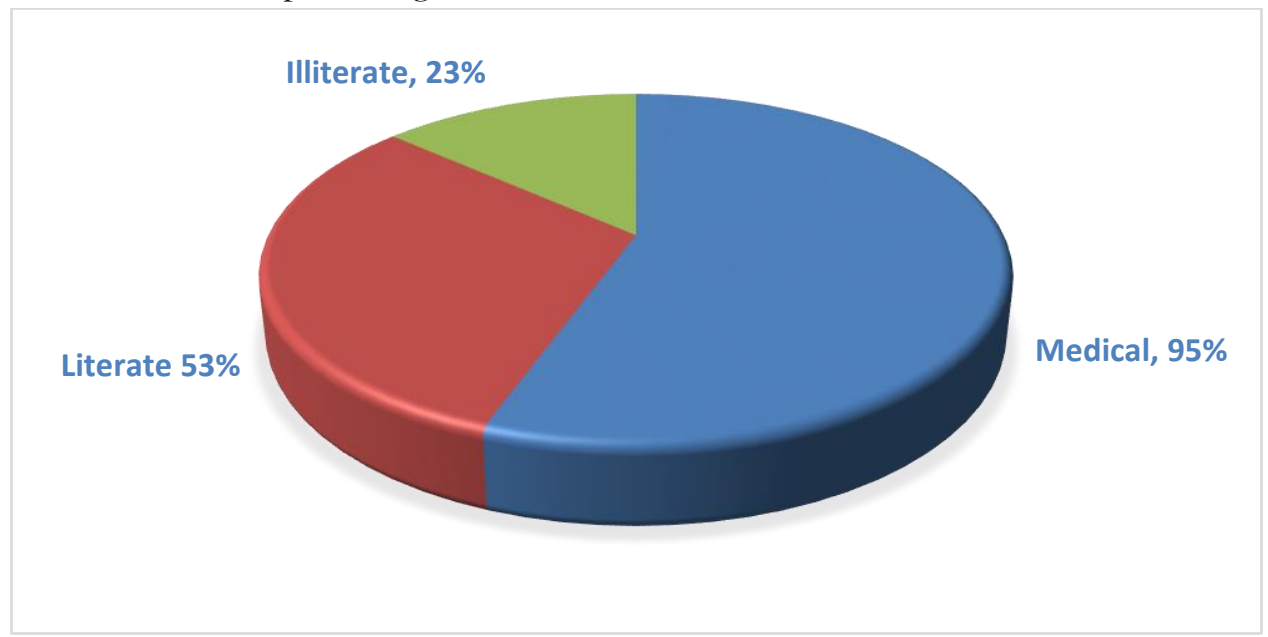

Figure 1: Awareness regarding lead poisoning in different populations

Table 1 and Figure 2 show that Literate layperson 72\%, Illiterate $71 \%$ and Medical professionals $73 \%$ have same view that children are mostly affected by lead poisoning.

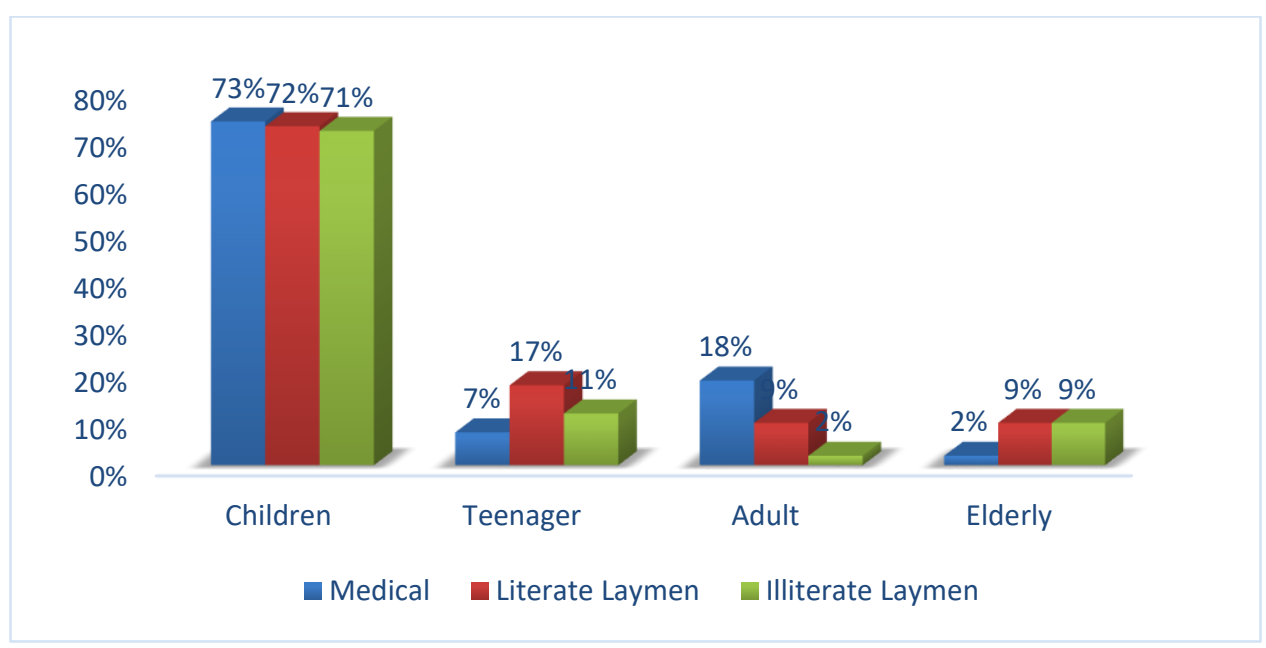

Figure 2: Population commonly affected by lead poisoning

Through different literature studies we also found that children are mostly affected by lead poisoning because of their metabolism and growth characteristics [24, 25]. Lead poisoning can have continuous damaging effects on children, influencing the development of nervous, cardiovascular, digestive, urological, reproductive, and endocrine systems [26, 27]. Views about the sources of lead poisoning, Literate laypersons i.e. 38\%, Illiterate $27 \%$ and medical professional i.e. $54 \%$ stated that paints toys, utensils, plumbing, pollution, cosmetics, pencils and soil all are common sources of lead poisoning. Literature study however showed that house hold paints and surface soil are the main sources. Pollution due to gasoline emissions is another important source of lead 
poisoning [8]. Table 1 and Figure 3 show that the most common effect according to Literate laypersons i.e. $30 \%$ is mental impairment, it is kidney disease according to $41 \%$ illiterate laypersons but according to medical professional's i.e. $43 \%$ is neurological effect.

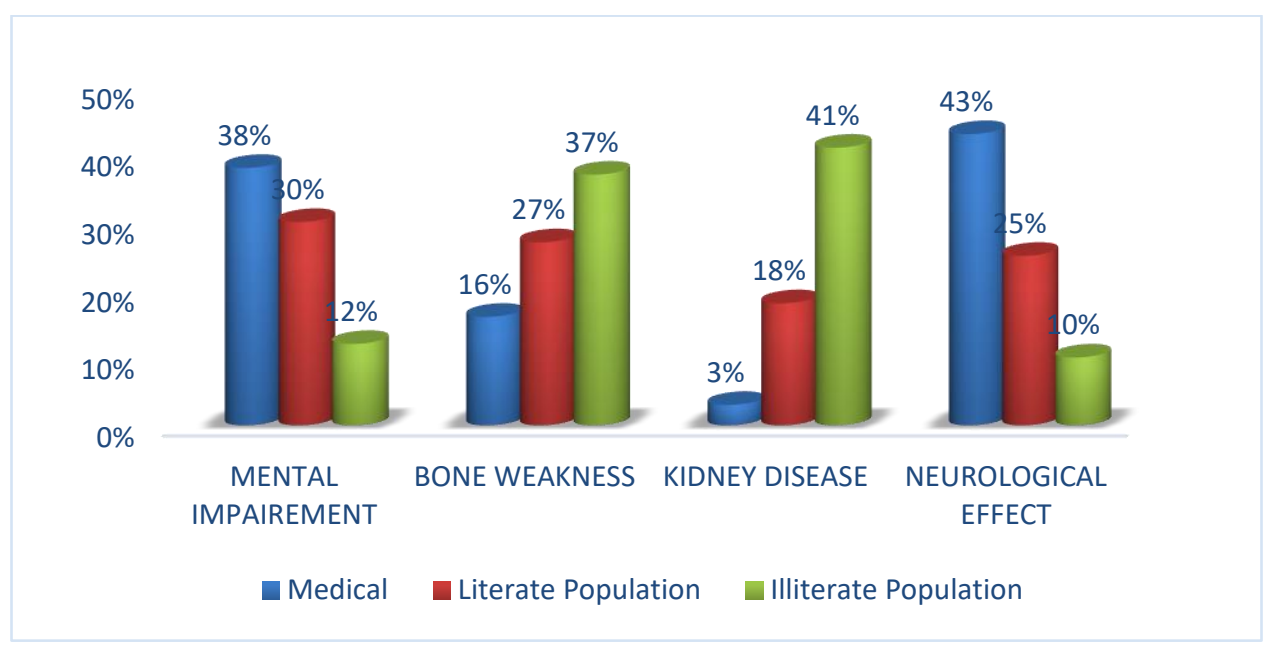

Figure 3: Symptoms Commonly Observed

Different studies showed that mental impairment and neurological both are common effects that come after lead poisoning. Because in most of the cases children are affected. Lead can easily penetrate the brains of children because their blood-brain barriers are not fully developed. Lead poisoning can have continuous damaging effects on children, influencing the development of nervous system. The earliest and most obvious influences of lead on the nervous system of children include neurobehavioral changes except for a decline in intelligence $[13,14]$. Survey study about the common route involved in lead poisoning showed that according to both literate laypersons i.e. $35 \%$ and medical professionals i.e. $73 \%$ oral and inhalation are common routes involved in lead poisoning while illiterate layperson i.e.73\% said that oral route is mostly involved in lead poisoning. Literature studies also agree with it suggesting lead accumulates in body by inhalation of lead contained pollution and orally through paints, soil, cosmetics and different other sources [28]. According to Figure $495 \%$ Medical, 11\% Illiterate where as 69\% Literate population is aware that lead poisoning can affect unborn babies (fetus).

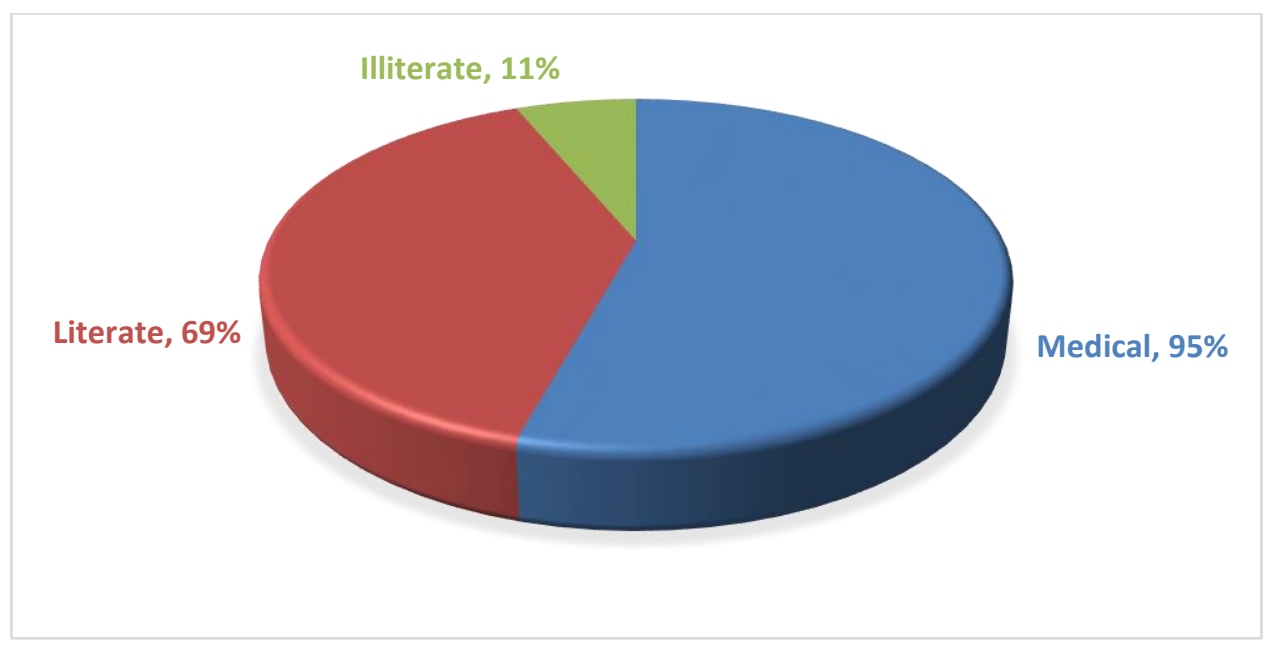

Figure 4: Awareness regarding effects of lead on unborn babies 
Sarfaraz et al., Adv. J. Grad. Res.; Vol. 1 Issue 1, pp: 3-13, January 2017

Figure 5 shows that in our population 69\% literate laypersons, 95\% medical professionals and only $11 \%$ illiterate laypersons have awareness that pollution is the common route through which lead affects the unborn babies. Literature study showed that lead is also found in cosmetics like kajal pencils, lipstics etc which are used by women so there is a risk of lead accumulation in body of mother which can rapidly effect unborn babies because Lead crosses the placenta during pregnancy and has been associated with intrauterine death, prematurity, and low birth weight $[8,9]$.

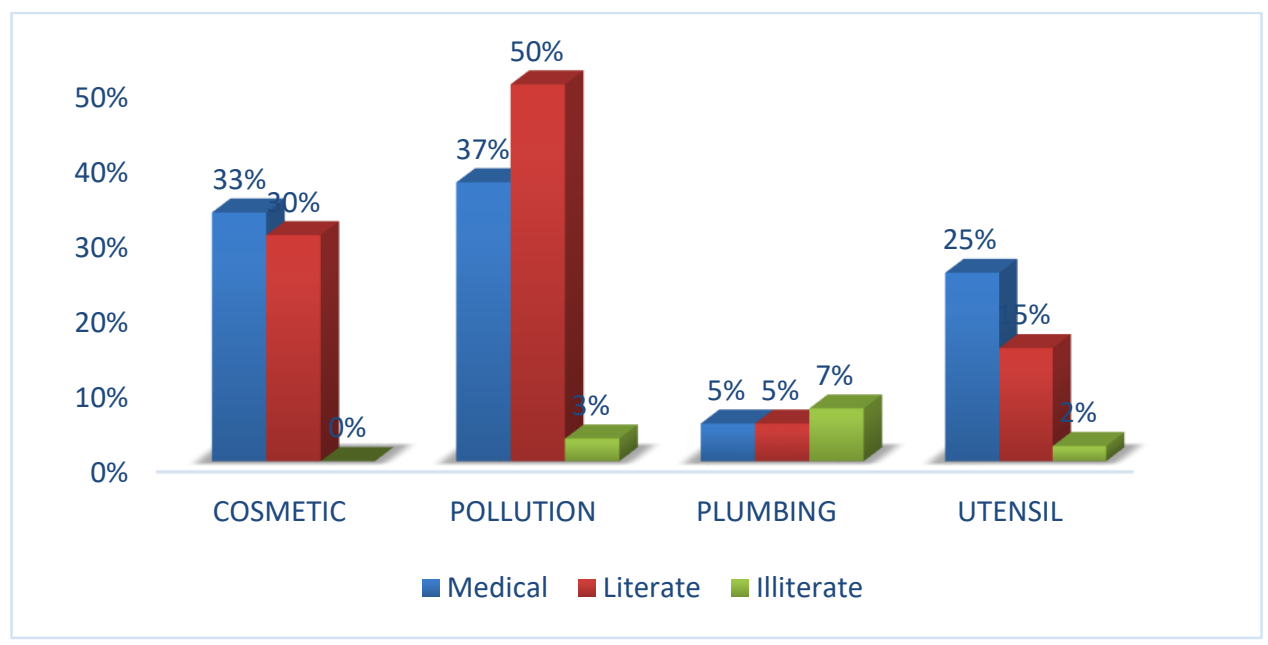

Figure 5: Sources through which lead poisoning occurs in unborn babies

Calcium, Iron and Vitamin C deficiency in the body indicates lead poisoning, Figure 6 shows that $52 \%$ literate laypersons and $71 \%$ medical profession have positive view while only $19 \%$ illiterate laypersons have awareness about this. Literature study also supports this that these nutrients decrease the lead absorption in the body so when deficiency of these nutrients occurs in the body there is a greatest risk of high level of lead absorption which leads to toxicity. Diets that contain these nutrients in large amount can help to reduce lead poisoning. $45 \%$ layperson and 36\% medical professional prefer milk as a common dietary source of these nutrients. According to literature studies banana, yogurt, cheese, meat, orange also contain these nutrients in large amount [16].

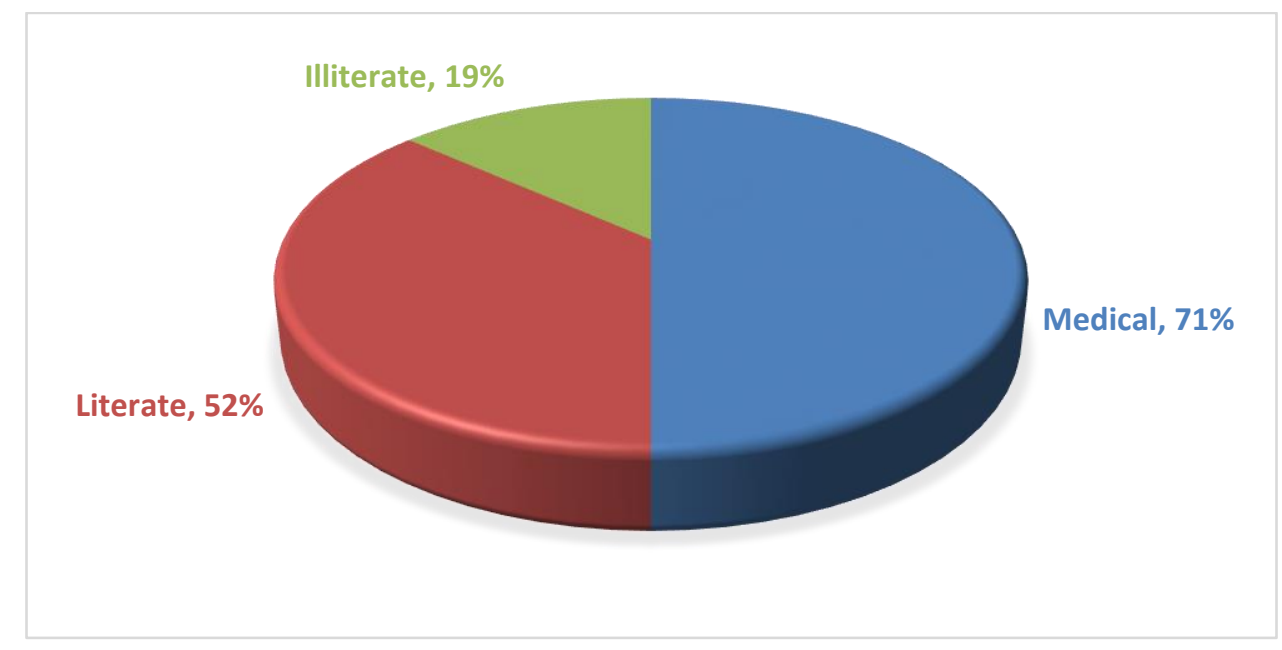

Figure 6: Awareness regarding lead poisoning indicators 
Literature study shows that lead poisoning leads to severe anemia through interfering with heme biosynthesis. Alpha- aminolevulinic acid (ALA) dehydratase is the enzyme in heme pathway (that condenses two molecules of ALA to form mono pyrrole Porphobilinogen) is more susceptible to the inhibitory effect of lead. Lead binds to the sulfhydyl groups, blocking the active site on the enzyme. The second enzyme which is inhibited in heme pathway due to lead poisoning is ferrochelates also called heme synthase which inserts ferrous iron in to the protoporphyrin IX to form the end product heme, as a result ALA and Protoporphyrin increased in the urine in the subject with lead poisoning [29, 30]. Figure 7 represents the finding that $51 \%$ literate laypersons and 78\% medical professionals agreed that other nutrients like Vitamin B1 and Vitamin $\mathrm{D}$ also help to excrete lead from brain and bone respectively, while only $7 \%$ illiterate laypersons showed positive thinking about this. Literature evaluation also showed that vitamin $\mathrm{D}$ can play a role in decreasing the quantity of lead stored in the bone, and B1 (thiamine), specifically increases excretion of lead from the brain [17].

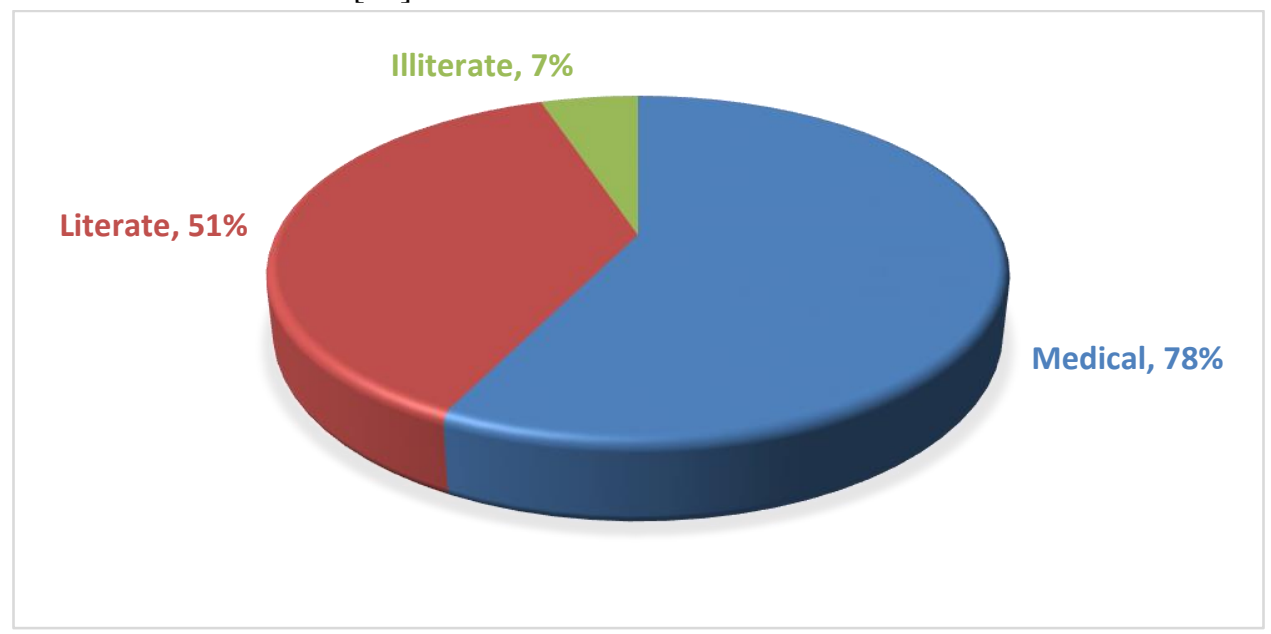

Figure 7: Awareness regarding vitamins which help in lead excretion

About the role of herbal remedies to overcome lead poisoning survey studies and Figure 8 showed that 25\% literate laypersons and 35\% medical professionals have not any idea but $20 \%$ laypersons and $45 \%$ medical professionals said that herbal remedies like turmeric, Glycerrbiza glabra and fennel seeds all are helpful in reducing lead poisoning while $47 \%$ illiterate laypersons said that turmeric is helpful in reducing lead poisoning. Literature studies do not show any significiant results that herbal remedies are helpful in reducing lead poisoning.

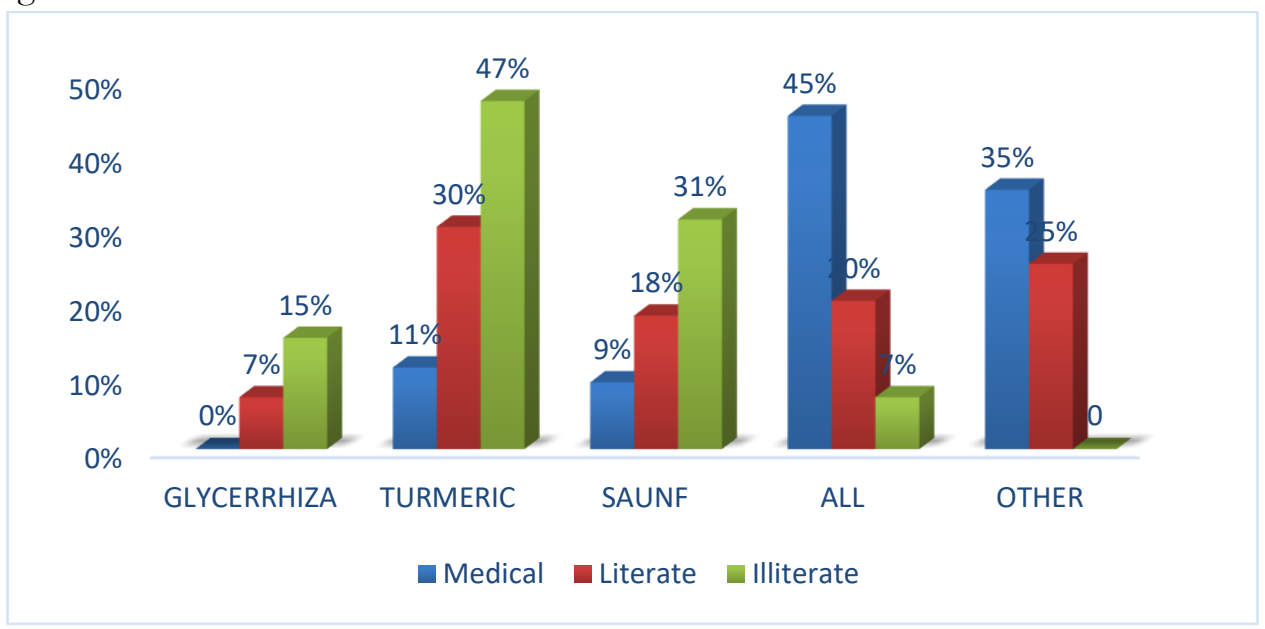

Figure 8: Awareness regarding herbal remedies for lead poisoning treatment 
About the pharmacological treatment of lead poisoning Figure 9 shows that only $17 \%$ literate laypersons and $3 \%$ illiterate laypersons are aware while $87 \%$ medical professionals have awareness regarding it. Medical professionals said that chelation therapy, EDTA and penicillamine are among the widely used therapy but among these chelation therapy is the best one. Literate laypersons and illiterate laypersons have insignificant idea.

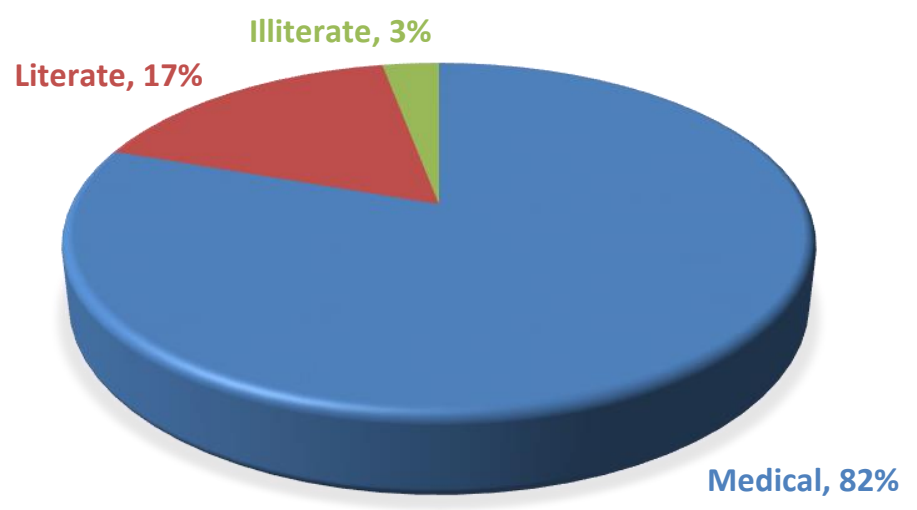

Figure 9: Awareness regarding pharmacological treatment of lead poisoning

Literature studies also found that chelation therapy and EDTA are used most commonly. This treatment binds to accumulated lead. The lead is then excreted in urine [26, 27]. Penicillamine is also used to excrete lead from body but the use of this oral agent is less in our population as compared to chelation therapy and EDTA [28]. Figure 10 shows that 63\% literate laypersons, 67\% illiterate laypersons and 68\% medical professionals gave the view that through awareness we can prevent lead poisoning incidents.

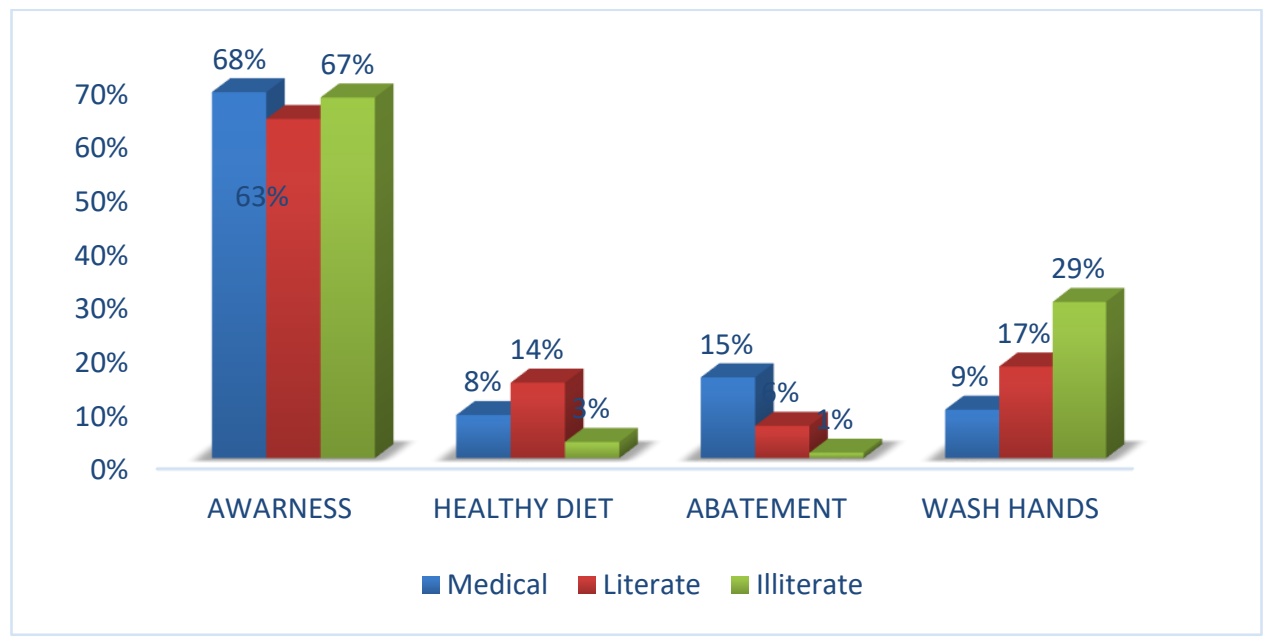

Figure 10: Awareness regarding preventive measures to overcome lead poisoning

In our view for the prevention of lead poisoning in any population, awareness is the basic factor. Persons should know what is lead poisoning, how it effects, what are the treatment and preventive measures that can be adopted to overcome it. Healthy diets, Healthy environment, avoid use of lead containing objects (avoid exposure to lead paints through abatement, lead free cosmetics, keep house clean etc.) are the factors which 
can help to reduce lead poisoning in our population. Table 2 shows that there is highly significant awareness regarding lead poisoning, its routes, effect in pregnancy, role of vitamins and nutrients as well as pharmacological treatment in medical population as compared to laypersons.

\section{Conclusions}

From the above study, we concluded that majority of our population (Medical and Literate) have awareness about lead poisoning having idea about sources and effects produced after it but majority of Illiterate population is still unaware about it. Over all, Layperson population were not much aware about the pharmacological treatment (chelation therapy). Majority of population said that awareness is major preventive action. Furthermore, there is a need to create awareness among the layperson population especially Illiterate ones to get medical help in case of constant prevalence of symptoms as well as the dietary modifications to take to overcome symptoms.

\section{How to cite this article:}

Sarfaraz, S., Naz, A., Shahid, A., \& Qayyum, M. (2016). Lead Poisoning: Awareness in Medical and Non-Medical Population of Karachi. Advanced Journal of Graduate Research, 1(1), 3-13. doi: https://doi.org/10.21467/ajgr.1.1.3-13

\section{References}

[1] Mark C. Henry, Edward R. Stapleton, "Poisoning And Overdoses" , EMT Prehospital Care, Published by Jones \& Bartlet, 2010; $4^{\text {th }}$ edition:362

[2] Carol D Tamparo, Marcia A Lewis, "Effect Of Physical and Chemical Agents", Diseases of the Human Body,Published by F.A.Devis Company,2011; $5^{\text {th }}$ edition:13

[3] Nicholas Bateman, Robert D. Jefferson, Dr., John P. Thompson, Dr., Simon H. L. Thomas, "Epidemiology of Poisoning” , Toxicology, Published by Oxford University Press 198 Medison Avenue $2014 ; 1^{\text {st }}$ edition:2

[4] By Dorothy A. Drago, "Poisoning”, Living Safely, Aging Well: A Guide to Preventing Injuries at Home ,Published by Johns Hopkins University Press, 2013: 73

[5] Stephen R.Thorn and Lon w.Keim , "Carbon monoxide poisoning: A Review epidemiology, pathophysiology, clinical findings, and treatment options including hyperbaric oxygen therapy" , Journal of Toxicology: Clinical Toxicology, published by Taylor \& Francis Group, 2008; 27(3):141-156

[6] L F Prescott, R N Illingworth, J A Critchley, M J Stewart, R D Adam, A T Proudfoot , "Intravenous N-acetylcystine: the treatment of choice for paracetamol poisoning", Br Med Journal , 1979; 2:1097

[7] Sven Hernberg, "Lead Poisoning in a Historical Perspective" , American Journal Of Industrial Medicine, published by WileyLiss,Inc.,2000; 38:244-254

[8] Nikolas C Papanikolaou, Eleftheria G Hatzidaki, Stamatis Belivanis, George N Tzanakakis, Aristidis M Tsatsakis, "Lead toxicity update. A brief review.", Journal of Medical Science,2005; 11:10

[9] Mustafa Aral, "Air Pathway Analysis”, Environmental Modeling and Health Risk Analysis (Acts/Risk), Springer publication, 2010:97

[10] Naser A. Anjum, Iqbal Ahmad, M. Eduarda Pereira, Armando C. Duarte, Shahid Umar, Nafees A. Khan, "Current Status of Toxic Metals Addition to Environment And its Consequences", The Plant Family Brassicaceae: Contribution Towards Phytoremediation, Springer publication, 2012; $21: 59$

[11] Randolph K. Byers, Elizabeth E. Lord, "Late Effects Of Lead Poisoning On Mental Development”, JAMA Pediatrics , 1943; 66(5):471494.

[12] Edward L. Baker, Jr., David S. Folland, T. A. Taylor, Myron Frank, Wendy Peterson, George Lovejoy, Dennis Cox, Jere Housworth, and Philip J. Landrigan. "Lead Poisoning in Children of Lead Workers - Home Contamination with Industrial Dust", The New England Journal Of Medicine, 1977; 296:260-261

[13] Cathie Robertson, " Lead Exposure In Children Affects Brain and Behaviour”, Safety,Nutrition \& Health In Early Education, $6^{\text {th }}$ edition: 387

[14] Jessic Wolpaw Reyes, "Lead Exposure And Behaviour : Effects On Antisocial And Risky Behaviour Among Children And Adolescents" ,2012:6-7

[15] Patrick, Lyn. "Lead toxicity, a review of the literature. Part I: exposure, evaluation, and treatment." Alternative Medicine Review ,2006; 11(1): 5

[16] O A Levander, "Lead toxicity and nutritional deficiencies", PMC Journal, $1979 ; 29: 115-125$.

[17] Hwan-Cheol Kim, Tae-Won Jang, $\triangle$ Hong-Jae Chae, Won-Jun Choi, Mi-Na Ha, Byeong-Jin Ye, Byoung-Gwon Kim, Man-Joong Jeon, SeYeong Kim, and Young-Seoub Hong, "Evaluation and management of lead exposure", PMC Journal, 2015; 27: 30.

[18] Jennifer A. Lowry, "Management of the Child with Elevated Blood Lead Concentrations", Oral Chelation Therapy for patients with lead poisoning ,2010:8 
[19] J N Gordon, A Taylor, and P N Bennett, "Lead poisoning: case studies",PMC journal, 2002; 53(5): $451-458$.

[20] Goldberg A, Smith JA, Lochhead AC. "Treatment of Lead-poisoning with Oral Penicillamine” ,British Medical Journal,1963; 1(5340):1270-1275.

[21] E Friedheim a, J.H Graziano b, D Popovac c, D Dragovic c, B Kaul d, "Treatment of Lead Poisoning by 2,3-Dimercaptosuccinic acid", The Lancet, 1978; 2(8102):1234-1236

[22] Shuangxing Hou, Lianfang Yuan, Pengpeng Jin, Bojun Ding, 1 Na Qin, Li Li,Xuedong Liu,Zhongliang Wu,Gang Zhao,and Yanchun Deng, "A clinical study of the effects of lead poisoning on the intelligence and neurobehavioral abilities of children", PMC journal, 2013 ; 10: 13.

[23] Jia Cao ,Minming Li ,Yu Wang,Guangjun Yu ,Chonghuai Yan, “Environmental Lead Exposure among Preschool Children in Shanghai, China: Blood Lead Levels and Risk Factors”,PMC journal , 2014; 9(12):e113297

[24] I Romieu, E Palazuelos, M Hernandez Avila, C Rios, I Muñoz, C Jimenez, and G Cahero , "Sources of lead exposure” , PMC journal , 1994; 102(4): 384-389.

[25] Jerome O. Nriagu, a, Mary L. Blanksonb, Kwamena Ocranc, "Childhood lead poisoning in Africa: a growing public health problem" ,Science Of The Total Environment, Published by Elsevier B.V,1996;181(2):93-100

[26] J.S.Carra, "Lead poisoning exposure" ,Lead poisoning, 1995: 304

[27] Robert Brochin, "Cellular Effect of Lead Poisoning And Its Clinical Picture”, GU Journal of Health Sciences ,2008; 5:2

[28] Jacquelyn Cafasso, "Lead Poisoning", Health Line ,2016: 1-8

[29] Namrata Chhabra, “Effect of Lead poisoning on heme biosynthesis pathway" Clinical cases- Biochemistry For Medics , 2015 :1

[30] Michael R. Moore ,Abraham Goldberg ,Albert A. C. Yeung-Laiwah, "Lead Effects on the Heme Biosynthetic Pathway Relationship to Toxicity”, Annals of The New York Academy of Sciences, 1987:191

\section{Publish your research article in AIJR journals-}

$\checkmark$ Online Submission and Tracking

$\checkmark$ Peer Reviewed

$\checkmark$ Rapid decision

$\checkmark$ Immediate Publication after acceptance

$\checkmark$ Open Access (Articles freely available online)

$\checkmark$ Retain full copyright of your article.

Submit your article at journals.aijr.in 